\title{
Beggars' Problem in Akola City in Maharashtra State
}

\author{
Dr. Nileema Sarap, Sarap N. S. ,Mehta P.G. \\ Assistant Professor of Sociology, S. K. College, Akola, \\ Assistant Professor of English \\ Assistant Professor of Extension Education, College of Agriculture, Dapoli.
}

\begin{abstract}
This article is an attempt to understand and evaluate the beggars' problem in India, with special reference to Vidarbha region in the Maharashtra state. The present study provides the causes behind the begging problem and focuses on most important causes of the begging e.g. poverty, illiteracy, rituals, traditions, laziness and tendency of the acceptance of the circumstances and habitat. In the present analysis, social, economical and legal aspects will be studied, which would put light on the nature of beggars and views of the society towards them.

The survey analysis regarding beggars' problems shows the basic cause of the problem was the helpless old age persons. The law, social strata and thinking of religion are not adequate to alleviate the sorrow condition of the beggars. The Hindu culture says that it is the duty of the head of the family to look after all family members. But, the present study shows the changing nature of the society. The process of modernization, materialism and tendency of urban civilized society such as selfishness, individualism are increasing among the society. The changing lifestyle and speed are the obstacles which have influenced the middle class lifestyle. The schemes such as Shravanbal Yojana, common orphanages for beggars and old age persons are established by the government, but yet they are not found to be beneficial to a desired extent. Many disadvantaged persons are away from it, because such schemes need the legal documents which beggars can't provide.

While conducting this project, it was the need of the study to communicate with affected people. The Akola city was the field area of the work. To collect the data about the problem the interview method was adopted. The survey was carried out by interviewing about 200 beggars from Akola city in Maharashtra. To make the research unbiased, the discussions were carried with various resource persons, experienced citizens of various classes, police officers, social workers. The questions were formed to collect the data about their general information, their problem like living and health, their daily routine etc.
\end{abstract}

\section{Introduction}

Begging is the practice of imploring others to grant a favor, often a gift in the form money, with little or no expectations of reciprocation. However many felt they could not handle conventional jobs because of mental illness, physical disability or lack of skills. Begging is the social problem and awkward situation exists all over the world. The beggars are found at street, railway station, near temple, bus station and most of the public places. In the metropolitan cities these are found at traffic signals, markets, etc. The begging governed by the underworld gang is another kind of profession that endangers the society. The orphan children, kidnapped children are exploited through these gangs. When these beggars come to us for begging having helpless gestures on their face that move us and we pity on them. It is the grave scene which hampers the dignity of the society. In short, the people who can't do the physical or mental work for livelihood unwillingly and some physically fit people go for begging.

The present study is undertaken with the following specific objectives.

1. To understand the problem of begging in Akola city in Maharashtra state.

2. To identify the causes of begging.

3. To investigate the prospects of rehabilitation schemes for beggars.

\section{Analysis of Data}

The data collected through survey is formulated in the following tables.

The Table No. 1 gives the general information of the beggars. 
Table 1; General Information of the beggars.

\begin{tabular}{|l|c|c|c|c|}
\hline \multirow{2}{*}{ SI. No. } & Particulars & \multicolumn{2}{|c|}{ The statistical Data } & \multirow{2}{*}{$\begin{array}{c}\text { Percentage } \\
(\mathbf{n}=\mathbf{2 0 0})\end{array}$} \\
\cline { 3 - 5 } & & Category & Frequency & 21 \\
\hline 1 & Age & $\mathbf{2 0 - 4 0}$ & $\mathbf{4 2}$ & $\mathbf{2 3}$ \\
\hline & & $\mathbf{4 1 - 5 0}$ & $\mathbf{8 4}$ & $\mathbf{4 2}$ \\
\hline $\mathbf{n}$ & & $\mathbf{6 1 - 7 0}$ & $\mathbf{2 8}$ & $\mathbf{1 4}$ \\
\hline & & $\mathbf{7 1 - 8 0}$ & $\mathbf{1 2 0}$ & $\mathbf{6 0}$ \\
\hline 3 & Education & Illiterate & $\mathbf{4 0}$ & $\mathbf{2 0}$ \\
\hline & & Primary & $\mathbf{4 0}$ & $\mathbf{2 0}$ \\
\hline
\end{tabular}

The above table states that the ratio of beggars is found 65 per cent from the age group 41-70. The lowest ratio found in the age group of 20-40 years. The status of education was found miserable. The 60 per cent interviewees were illiterate while primary and secondary education acquired people were 20 per cent each. Female and male beggars found to be 63.5 and 36.5 , respectively.

Table No. 2: Data about relatives and Shelter of beggars.

\begin{tabular}{|l|c|c|c|}
\hline S1. No. & Particulars & Frequency & $\begin{array}{c}\text { Percentage } \\
(\mathbf{n}=\mathbf{2 0 0})\end{array}$ \\
\hline 1. & Live at relatives House & 42 & $\mathbf{2 1}$ \\
\hline 2 & Live at own House & $\mathbf{0 4}$ & $\mathbf{0 2}$ \\
\hline 3. & No proper shelter & 154 & 77 \\
\hline
\end{tabular}

Table 2 shows that 21 per cent people were having relatives. Only 2 per cent were having their own homes and 77 per cent people were homeless. The above statistics shows that there is no proper shelter to these people. This means that most of them not had their own shelter. They lived on either footpath or temple or railway station.

The enquiry regarding the reasons behind begging was made.

Table 3: Causes of begging

\begin{tabular}{|l|l|c|c|}
\hline $\begin{array}{l}\text { Sl. } \\
\text { No. }\end{array}$ & \multicolumn{1}{|c|}{ Particulars } & Statistics & $\begin{array}{c}\text { Percentage } \\
(\mathbf{n = 2 0 0})\end{array}$ \\
\hline 1 & Illiteracy & 06 & 03 \\
\hline 2 & Having no sources of Food Gain & 56 & 28 \\
\hline 3 & Can't do work due to old age & 56 & 28 \\
\hline 4 & Having no relatives & 22 & 11 \\
\hline 5 & Illness & 06 & 03 \\
\hline 6 & The children do not take care & 16 & 08 \\
\hline 7 & Domestic conflicts & 12 & 06 \\
\hline 8 & Unemployment & 22 & 11 \\
\hline 10 & Traditional occupation & 04 & 02 \\
\hline
\end{tabular}

The above data shows the causes of begging. The more cases found are orphanage, old- age, no food gain, conflict between the parents and children. It can be said that this is collective effect of the social, psychological and economical factors behind the main causes of the begging.

Table 4: Beggars' awareness about their rights and responsibilities and participation in government policies

\begin{tabular}{|l|l|c|c|c|c|}
\hline \multirow{2}{*}{ Sl. No. } & \multicolumn{1}{|c|}{ Particulars } & \multicolumn{3}{c|}{ Statistics (n=200) } \\
\cline { 3 - 6 } & & Yes & $\mathbf{\%}$ & No & $\mathbf{\%}$ \\
\hline 1 & Voting in municipality elections & 58 & 29 & 142 & 71 \\
\hline 2 & Voting in other elections & 122 & 61 & 78 & 39 \\
\hline 3 & Knowledge about begging Prohibition law & 38 & 19 & 162 & 81 \\
\hline 4 & Government officers' role in opposing begging & 20 & 10 & 180 & 90 \\
\hline 5 & Acceptance of rehabilitation at other places & 156 & 78 & 44 & 22 \\
\hline 6 & Acceptance the facility of their wards' education & 60 & 30 & 16 & 08 \\
\hline 7 & Knowledge about the parent care law & 18 & 9 & 182 & 91 \\
\hline
\end{tabular}

The interview schedule was prepared to seek the information from beggars for the issues related to them such as whether they were aware of the basic living things. The data shows the information about the voting in election, 61 per cent people vote while 39 percent people do not vote in the various elections. This clearly indicates that they are citizens of India. Some of them i.e. $29 \%$ people also vote in municipality election. 19 per cent people were aware about the begging prohibition law, while $81 \%$ people were found not aware about it. The government officers make their inquiry. Further, the data shows that they are eager to live in well sheltered home, if the rehabilitation is done. They want to live in family or institute (78 per cent). 
One case study shows that social binding in the relationship is going to be vanished. An old age person has two children one boy and girl. Both of them were married having small daily wages work. He admitted that his son, son in law and daughter in law were averse for his feeding and other casual expenses. When he went to his daughter's house, his son in law had not accepted the permanent stay at his home. Here we have to accept that the Hindu tradition allows the man's father with his son and son in law. But the daughter can't feed her father. This case belonged to lower income class family. The traditions are mandatory to this class family. When there is not any option for the adjustment the people takes the help of traditions. So that man of 72 was living in front of the temple. He said, that there must not be any conflict because of him at his son and daughter' house.

This reality is the worst condition of the society. Some orphan people don't get other help but the people having their own son or daughter or relatives were experiencing the intolerable situations. Again, these old age people were not aware about the laws and regulations or the decisions of the court on family affairs. The nurturing of the mother and father with respectful manner at home was the law made in 2006. But these people were not aware of it or bothered about it. Illiteracy and poverty are the main features of such problem.

\section{Conclusions}

The following conclusions are drawn based on the analysis of the collected data.

1. The beggars found from the total number of interviewees were above the age of 41, which comes to 65 per cent. The illiterate people were 63 per cent the old age and illiteracy were the main causes of begging.

2. Exactly 77 per cent beggars were not having relatives, 12 per cent of them didn't have any support from relatives. While, 11 per cent respondents have relatives, but they were not giving shelter or nurturing them are. So being orphan was one of the root causes of this problem.

3. Out of the total interviewee 26 per cent lived at temple, 21 per cent at railway station. Only 2 per cent lived at their homes and some people had not exposed their living place due to the fear of police. Thus it is clear that they didn't get adequate support and protection from the society.

4. Precisely 31 per cent people wanted to do the work but the jobs were not available to them. While, 69 per cent people were of old age and some of them were handicap. This means that they didn't have livelihood security in terms of earnings. Hence, there were no other options for the beggars, so they accepted begging.

5. Practically 13 per cent people stated that it was the easy for them to do a job so they preferred begging.

6. Above statistics shows that old age, physical disability and laziness are some other causes of begging. Economical, Social, Psychological causes are behind these problems.

7. 39 per cent people took part in the elections. Out of them 29 per cent people were the municipality citizens. These people may be participating in the elections for financial benefit.

8. The begging prohibition law was known to 19 per cent people, while $81 \%$ were not aware about it. Just 10 per cent people told that the some government officers like police used to make their enquiry. The unawareness about the law and apathy towards the implementation of laws were the most important causes. This clearly indicates urgent need for making awareness about prohibition law among the beggars.

\section{Recommendations}

Following recommendations are made after the research and observations by the survey are:

1. Most of the respondents of the present survey were old age people. There is a need for provision of old age home in the Vidarbha region.

2. To look after the parents, children, spouse, and disabled is the prime duty of the head of the family. This law is formulated under criminal procedure code section 125 . This law needs to be extensively known among Indian citizens.

3. The most of old age people are not aware about the law for old age. The social awareness campaign is the needed to tackle such problems.

4. Unemployment is the main problem. The rehabilitation and livelihood should be provided to these people through proper policy implementation.

5. Some small children are forced to beg. Provision of the education of these children is required on the large scale.

6. In the present project, women beggars are found more in number. It proves the need of special rehabilitation for women folk for their security.

Thus, all these laws and schemes will not be beneficial and effective, unless and until they are implemented through properly organized system. 


\section{References:}

[1]. Brendo Jo, Bruggment and Gary 1. Albrnch. Arts and Humanity 2012. The Ohio State University

[2]. Gay, Jahn. The Beggars Opera

[3]. Jock, Young. Crossing the Border to these Wet \& Windy Shows

[4]. Ruppuswami, P. Our Beggars Problems

[5]. Times of India, Article. 